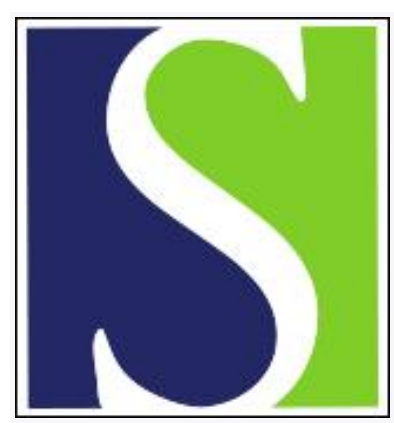

Scand J Work Environ Health 1983;9(3):265-271

https://doi.org/10.5271/sjweh.2410

Issue date: Jun 1983

Exceptional pharmacokinetics of trivalent chromium during occupational exposure to chromium lignosulfonate dust.

by Kiilunen M, Kivisto H, Ala-Laurila P, Tossavainen A, Aitio A

This article in PubMed: www.ncbi.nlm.nih.gov/pubmed/6612268 


\title{
Exceptional pharmacokinetics of trivalent chromium during occupational exposure to chromium lignosulfonate dust
}

\author{
by Mirja Kiilunen, MSc, ${ }^{1}$ Helena Kivistö, MSc, ${ }^{1}$ Pekka Ala-Laurila, ${ }^{2}$ \\ Antti Tossavainen, DTech, ${ }^{1}$ Antero Aitio, MD'
}

\begin{abstract}
KIILUNEN M, KIVISTÖ H, ALA-LAURILA P, TOSSAVAINEN A, AITIO A. Exceptional pharmacokinetics of trivalent chromium during occupational exposure to chromium lignosulfonate dust. Scand $j$ work environ health 9 (1983) 265-271. The excretion of chromium in the urine of workers exposed to chromium lignosulfonate was studied. The chromium in the dust was in the trivalent (III) oxidation state, and $30 \%$ of the particles were less than $5 \mu \mathrm{m}$ in diameter. Chromium (III) lignosulfonate dust was rapidly absorbed, and a peak of urinary excretion was seen immediately after exposure. No appreciable accumulation of chromium occurred over $3 \mathrm{~d}$, as evaluated by comparison with preshift urinary chromium concentrations. The addition of ethylenediaminetetraacetate to the urine of exposed persons greatly enhanced the capacity of chromium to traverse a dialysis membrane; the same effect was seen with chromium (III) chloride. It is concluded that chromium (III) lignosulfonate yields chromium (III), which acts pharmacokinetically like water-soluble hexavalent chromium compounds.
\end{abstract}

Key terms: biological monitoring, carcinogenic metals, hexavalent chromium, pulmonary absorption, urinary excretion.

Workers exposed to chromates in chromate and chromium pigment production have been shown to have an increased risk of lung cancer, whereas no increase in risk has been noted for people exposed to trivalent (III) chromium compounds, eg, in the ferrochromium industry $(1,2,5)$. Hexavalent (VI) chromium compounds also appear to be more carcinogenic in experimental animals than are chromium (III) compounds (5). Similarly, only chromium (VI) seems to be mutagenic; it is also much more toxic than chromium (III), both in animals and in cell cultures $(3,5,7,10,11)$. No toxic effects have been seen in workers after years of exposure to inorganic chromium (III) compounds (6). Because of these marked differences in

1 Institute of Occupational Health, Helsinki, Finland.

2 Serlachius Oy, Tampere, Finland.

Reprint requests to: Dr A Aitio, Laboratory of Biochemistry, Institute of Occupational Health, Arinatie 3, SF-00370 Helsinki 37, Finland. toxicity, it is very important to determine the oxidation state of chromium compounds to which workers are exposed.

The differences in toxicity between triand hexavalent chromium compounds are probably due in part to their different abilities to penetrate biological membranes. Chromium (VI) derivatives easily penetrate cell membranes and are easily absorbed from the gastrointestinal tract and lungs, whereas chromium (III) compounds traverse biological membranes only with difficulty $(5,7,10)$.

Chromium lignosulfonate is used as a conditioner in oil drilling. In this compound chromium is attached to lignin, a polymer which represents $25-30 \%$ of the mass of wood; it is a by-product in the sulfite cellulose process and represents approximately $6 \%$ of the waste liquors from pulp mills using that process. In routine biological monitoring, we noted that people exposed to chromium lignosulfonate exhibited high concentrations of chromium in their urine. Because it was 
considered highly probable that the chromium in lignosulfonate is in the trivalent oxidation state, this finding was in contrast to what was expected. In this paper we report the results of a kinetic study of five people exposed to chromium lignosulfonate.

\section{Materials and methods}

\section{Manufacturing process and subjects}

Chromium lignosulfonate (chromium lignin) is produced from lignosulfonate and sodium dichromate. Dichromate is added to the lignin slurry at $\mathrm{pH} 1.0$, and the mixture is boiled. The $\mathrm{pH}$ is slowly raised to 12 with the addition of alkali. During boiling, chromium attaches to the lignin polymer and is simultaneously reduced to the trivalent oxidation state. The product is dried, and a fine, dark powder is formed. At the time of this study the process was carried out for three consecutive days (other derivatives of lignin being produced before and after that of chromium) on a continuous three-shift basis. The subjects were five people working in the packing department of the factory; they were exposed exclusively to the final product and not to the dichromate used in the process. Three of the subjects wore protective masks.

\section{Industrial hygiene measurements}

Dust samples were collected on cellulose ester membrane filters with personal sampling pumps in the breathing zone of the five workers. The sampling periods covered the workhours and thus comprised approximately two 4-h periods on Wednesday, Thursday, and Friday. In addition airborne dust samples were taken at two stationary locations within the work area.

The total amount of dust in the samples was determined by weighing. The chromium content was measured by use of an atomic absorption spectrophotometer with an air-acetylene flame. The morphology of the dust was studied by phase contrast optical and scanning electron microscopy.

The valence state of the chromium in the lignosulfonate was determined by diphen- ylcarbazide color reaction (10) in an aqueous solution of the dust, as described previously (12), and directly in dry dust by $\mathrm{X}$-ray photoelectron spectroscopy (8). The sample was bombarded with a photon flux of $\mathrm{Al} \mathrm{K}$ radiation. In all samples the total spectrum from 1,500 to $500 \mathrm{eV}$ was measured, and special spectra were scanned for carbon $1 \mathrm{~s}$ and chromium $2 \mathrm{p}_{3 / 2}$ emission lines. Because such samples are not conductors, they become charged during measurement; a correction is made by taking carbon in line $(285.0 \mathrm{eV})$ as a constant (8).

\section{Biological monitoring}

Blood samples were drawn into heparinized tubes before exposure and at midday on the third day of exposure. All urine excreted during the $3 \mathrm{~d}$ of exposure was collected, in four portions per day. In addition spot urine samples were collected on six mornings after the exposure. Precautions were taken to prevent contamination of the urine samples by ambient air before and after collection. The sample vials (polyethylene) were allowed to stand in a $10 \%$ solution of Deconex ${ }^{(i)}$ overnight and were rinsed several times with distilled water.

Before the samples were collected the workers changed clothes and had a shower in a building separated from the factory area.

The chromium concentration in urine was measured with a Perkin-Elmer 400 atomic absorption spectrophotometer with electrothermal atomization (HGA 74). The samples were diluted 1: 10, and this dilution was injected into a pyrolyzed graphite tube by the Perkin-Elmer autosampling system AS-1 (12). The concentrations of chromium in blood were also determined by electrothermal atomization (P-E 4000, HGA 400) with direct dilution (Kiilunen, to be published). Standards were made by the addition of potassium chromate to urine and to blood, and they were diluted daily. A chromium concentration of 0.02 $\mu \mathrm{mol} / 1$ caused an absorption of 0.0044 .

The relative density was measured with an ATAGO SPR-T2 refractometer. Creatinine concentrations were determined with the alkaline picrate reaction with the use of a Technicon Auto Analyser. 
Table 1. Chromium concentrations in air and in the urine (after shift) of five workers exposed to chromium lignosulfonate over $3 \mathrm{~d}$. Workers $\mathrm{A}, \mathrm{C}$ and $\mathrm{E}$ used protective masks (at least temporarily).

\begin{tabular}{|c|c|c|c|c|c|c|c|c|}
\hline \multirow[t]{2}{*}{ Worker } & \multicolumn{4}{|c|}{ Chromium in air $\left(\mu \mathrm{g} / \mathrm{m}^{3}\right)$} & \multicolumn{4}{|c|}{ Urinary chromium $(\mu \mathrm{mol} / \mathrm{l})$} \\
\hline & Maximum & Minimum & Mean & SD & Maximum & Minimum & Mean & SD \\
\hline $\begin{array}{l}A \\
B \\
C \\
D \\
E\end{array}$ & $\begin{array}{r}80 \\
78 \\
230 \\
91 \\
190 \\
\end{array}$ & $\begin{array}{r}24 \\
23 \\
2 \\
16 \\
5\end{array}$ & $\begin{array}{l}43 \\
39 \\
80 \\
34 \\
11\end{array}$ & $\begin{array}{r}21 \\
22 \\
99 \\
29 \\
5\end{array}$ & $\begin{array}{l}0.21 \\
0.43 \\
0.12 \\
0.59 \\
0.05\end{array}$ & $\begin{array}{l}0.12 \\
0.06 \\
0.02 \\
0.05 \\
0.01\end{array}$ & $\begin{array}{l}0.16 \\
0.16 \\
0.05 \\
0.23 \\
0.02\end{array}$ & $\begin{array}{l}0.04 \\
0.14 \\
0.04 \\
0.19 \\
0.01\end{array}$ \\
\hline
\end{tabular}

Chemical form of chromium in the urine

Chromium (III) chloride, potassium dichromate (VI), chromium lignosulfonate (all dissolved in urine), and urine from exposed people $(1 \mathrm{ml})$ were dialyzed $24 \mathrm{~h}$ against $25 \mathrm{ml}$ of $0.01-\mathrm{mol} / \mathrm{l}$ phosphate buffer, $\mathrm{pH} 7.4$, in the presence and absence of $5-\mathrm{mmol} / \mathrm{l}$ ethylene diaminetetraacetate (EDTA). The concentration of chromium inside and outside the dialysis tube was analyzed by electrothermal atomic absorption spectrophotometry.

\section{Results}

Concentration of chromium in workplace air

The total dust concentrations in air taken by the personal samplers varied from 0.1 to $12 \mathrm{mg} / \mathrm{m}^{3}$, and the chromium content of the air was between 5 and $230 \mu \mathrm{g} / \mathrm{m}^{3}$ (1 $\mathrm{mg}=19.23 \mu \mathrm{mol}$ ) (table 1$)$. Conspicuous differences were seen between individual exposures, with averages ranging from 11 to $80 \mu \mathrm{g} / \mathrm{m}^{3}$. In $30 \%$ of the samples, the chromium concentration was greater than $50 \mu \mathrm{g} / \mathrm{m}^{3}$. The chromium content of air collected in a control room and packing area (stationary sample collectors) ranged from 7 to $41 \mu \mathrm{g} / \mathrm{m}^{3}$. The dust contained approximately $2 \%$ chromium (range 1.0$4.2 \%$ ), whereas the final product contained $6 \%$ chromium. As determined by microscopy, $30 \%$ of the dust particles were smaller than $5 \mu \mathrm{m}$ in diameter. Most of the airborne dust was considered to be respirable because of its porous, spongy structure.

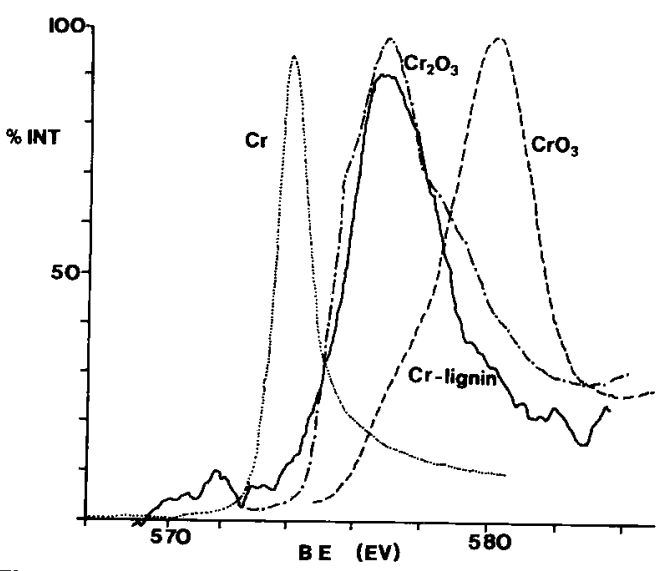

Fig 1. X-ray photoelectron spectra of various chromium compounds. ( $\mathrm{Cr}=$ metallic chromium, $\mathrm{Cr}_{2} \mathrm{O}_{3}=$ chromium (III) oxide, $\mathrm{CrO}_{3}=$ chromium (VI) oxide, $\mathrm{Cr}$-lignin = chromium lignosufonate, INT = intensity, $\mathrm{BE}=$ binding energy, $\mathrm{EV}=$ electron volts)

Oxidation state of chromium in the dust

X-ray photoelectron spectra of various chromium compounds are plotted in fig 1. The binding energies observed for the chromium, chromium (III), and chromium (VI) standards were 573.8, 575.2, and 578.6 $\mathrm{eV}$, respectively, and that measured for chromium lignosulfonate was $575.2 \mathrm{eV}$, indicating that the chromium in lignosulfonate is in the trivalent oxidation state.

When lignosulfonate dust was dissolved in water, no color was produced in the diphenylcarbazide reaction.

\section{Absorption of chromium in the body}

The concentration of chromium in whole blood from the people investigated was less than $0.02 \mu \mathrm{mol} / \mathrm{l}$ - the limit of detection - both before exposure and at midday 

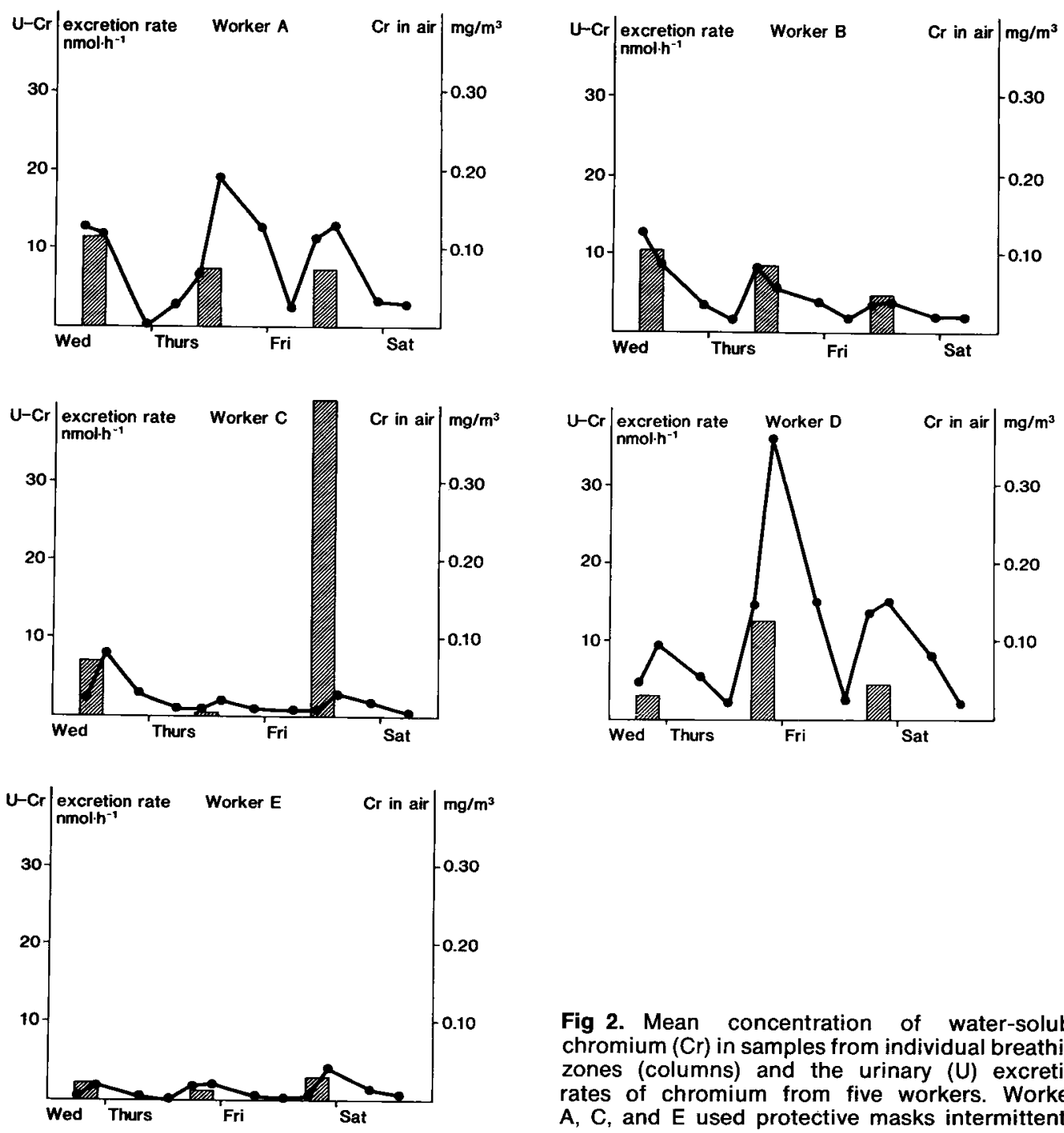

Fig 2. Mean concentration of water-soluble chromium (Cr) in samples from individual breathing zones (columns) and the urinary (U) excretion rates of chromium from five workers. Workers $A, C$, and $E$ used protective masks intermittently.

on the last day of exposure. Thus no increase could be detected in the concentration of chromium in the blood.

In contrast there was a clear increase in the urinary chromium content after exposure to chromium lignosulfonate dust (fig 2). Peaks of chromium excretion appeared toward the end or immediately after the period of exposure, a phenomenon indicating rapid absorption through the lungs and excretion through the kidneys. Qualitatively similar curves were obtained for the chromium concentration (either corrected to a relative density of 1.018 or uncorrected) and chromium excretion per mole of creatinine or chromium excretion

per unit of time. The amount of chromium excreted in the urine was dependent on the concentration of chromium in the air (fig 3). Calculated from this relationship, 1-2\% of the inhaled chromium (on the assumption that the ventilation rate was $20 \mathrm{l} / \mathrm{min}$ and all the chromium was respirable) was excreted in the urine. For the two persons not wearing protective masks the estimated concentration of chromium in the urine after an exposure of approximately $4 \mathrm{~h}$ to an air concentration of chromium of $50 \mu \mathrm{g} / \mathrm{m}^{3}$ was 0.22 and $0.33 \mu \mathrm{mol} / \mathrm{l}$ (11 and $17 \mu \mathrm{g} / \mathrm{l})$.

Two, three, four, five, six, and seven days after the exposure the highest recorded 
concentrations of chromium in the urine were $0.13,0.07,0.06,0.03,0.04$, and 0.03 $\mu \mathrm{mol} / \mathrm{l}$, respectively. (We regard 0.05 $\mu \mathrm{mol} / \mathrm{l}$ as the reference limit for nonexposed people.)

The time-dependent decrease in the chromium concentration of urine gave half-time estimates between 4 and $10 \mathrm{~h}$ when calculated on the basis of an open, one-compartment kinetic model.

\section{Chemical form of chromium in the urine}

To establish whether the chromium in the urine of workers exposed to chromium lignosulfonate remains attached to the lignin polymer, we undertook dialysis experiments. Their results are shown in table 2. Chromium (III) chloride, potassium chromate (VI), and chromium lignosulfonate were used as the reference compounds. Chromium (VI) was freely dialyz-

Fig 3. Relationship of urinary chromium (U-Cr) excretion ( $\mu \mathrm{mol} /$ workshift) with exposure to airborne chromium lignosulfonate (Air $\mathrm{Cr}$ ). The data for two persons $(+, 0)$ not wearing protective masks have been presented. The regression lines (least squares method) were $y=0.000788 x+0.00148$, $r=0.942$, and $y=0.00135 x+0.002203, r=0.943$. able (data not shown), but the concentrations of all the other chromium compounds were higher inside than outside

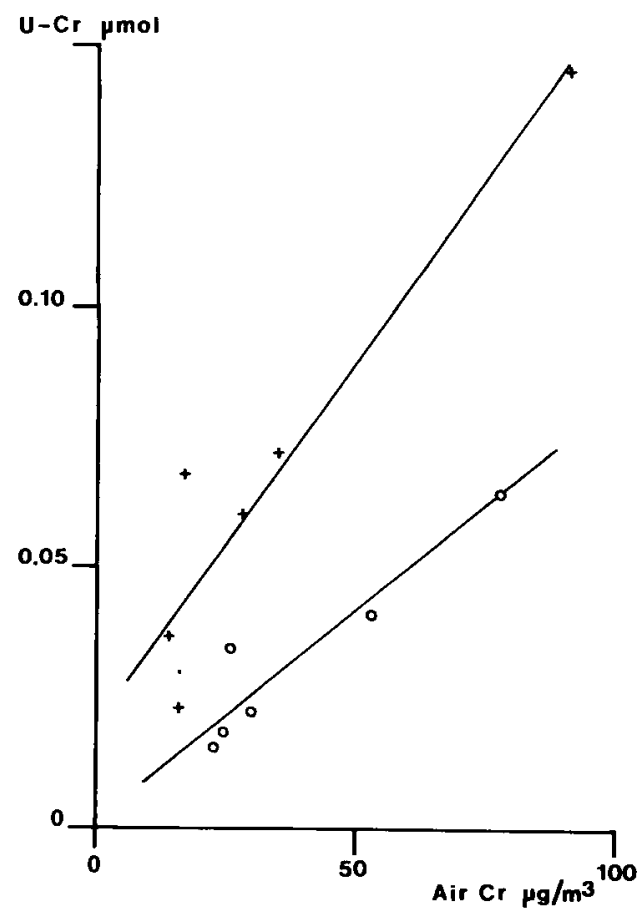

Table 2. Dialysis of chromium compounds. The compounds (in $1 \mathrm{ml}$ of urine) were dialyzed against

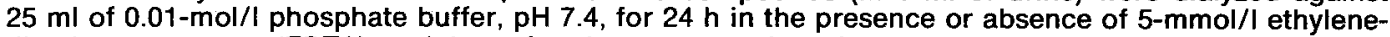
diaminetetraacetate (EDTA), and thereafter the concentration of chromium inside and outside the dialysis bag was determined.

\begin{tabular}{|c|c|c|c|}
\hline Compound $^{\mathrm{a}}$ & $\begin{array}{c}\text { Chromium } \\
\text { (nmol) }\end{array}$ & $\begin{array}{c}\text { Concentration } \\
\text { ratio } \\
\text { (inside : outside) }\end{array}$ & $\begin{array}{c}\text { Permeability } \\
\text { increase due } \\
\text { to EDTA }\end{array}$ \\
\hline \multicolumn{4}{|c|}{ Chromium (III) chloride } \\
\hline $\begin{array}{l}\text { - EDTA } \\
+ \text { EDTA }\end{array}$ & 0.058 & 3.5 & 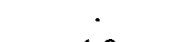 \\
\hline $\begin{array}{c}\text { + EDTA } \\
\text { Chromium lig }\end{array}$ & 0.058 & 2.2 & 1.6 \\
\hline \multicolumn{4}{|c|}{ Chromium lignosulfonate } \\
\hline + EDTA & 0.029 & $\begin{array}{l}23 \\
19\end{array}$ & 1.2 \\
\hline \multicolumn{4}{|c|}{ Urine of worker A } \\
\hline $\begin{array}{l}\text { - EDTA } \\
+ \text { EDTA }\end{array}$ & 0.077 & 5.4 & . \\
\hline \multicolumn{4}{|c|}{ Urine of worker A } \\
\hline - EDTA & 0.058 & 5.7 & $\cdot$ \\
\hline + EDTA & 0.058 & 3.1 & 1.8 \\
\hline \multicolumn{4}{|c|}{ Urine of worker B } \\
\hline - EDTA & 0.039 & 5.0 & . \\
\hline + EDTA & 0.039 & 2.5 & 2.0 \\
\hline \multicolumn{4}{|c|}{ Urine of worker $\mathrm{C}$} \\
\hline - EDTA & 0.096 & 5.6 & . \\
\hline + EDTA & 0.096 & 3.4 & 1.6 \\
\hline
\end{tabular}

a $-=$ not complexed with EDTA, $+=$ complexed with EDTA. 
the dialysis membrane. The concentration ratio inside : outside the membrane was about four times higher for lignosulfonate than for the urinary chromium compound. EDTA chelation decreased the concentration gradients of chromium (III) and of the urinary chromium compound by 1.6- to 2 fold but had no effect on that of chromium lignosulfonate.

\section{Discussion}

To our knowledge, this is the first kinetic study on the behavior of chromium lignin in humans. Korallus and co-workers (6) investigated workers exposed to chromium (III) oxide and chromium (III) sulfate. In workers who had been exposed for several years, they found a slight (less than twofold) increase in the urinary concentration of chromium in spot samples. The average exposure was considerably higher than in the present study - most workers were exposed to about $1 \mathrm{mg}$ of chromium $/ \mathrm{m}^{3}$, a level more than tenfold that seen in our study. Since Korallus et al used spot samples, without specifying the time of sampling, we cannot compare the kinetics of chromium excretion with those in our study. It is evident however that a considerably smaller portion of the inhaled chromium was excreted in the urine of workers exposed to chromium (III) oxide and chromium (III) sulfate than in the urine of those exposed to chromium lignosulfonate in the present study.

Two of the persons investigated did not wear protective masks. For these two, there was a close relationship between exposure and the urinary excretion of chromium (correlation coefficients 0.942 and 0.943 ). The slopes of the regression lines for these individuals were markedly different though. An airborne chromium concentration of $50 \mu \mathrm{g} / \mathrm{m}^{3}$ corresponded to urinary chromium levels of 11 and $17 \mu \mathrm{g} / 1$ (211 \& $327 \mathrm{nmol} / 1$, respectively). In studies of the excretion of chromium (VI) in the urine in people exposed to welding fumes, Tola \& co-workers (12) and Gylseth et al (4) reported that the corresponding figure for urinary chromium was approximately $40 \mu \mathrm{g} / \mathrm{l}(769 \mathrm{nmol} / \mathrm{l})$; somewhat lower values [about $10-20 \mu \mathrm{g} / \mathrm{l}(192-385 \mathrm{nmol} / 1)$ ], were reported by Mutti et al (9). It is thus clear that the amount of chromium ab- sorbed from lignosulfonate dust is of the same order of magnitude as that from chromium (VI) fume. Comparisons like this are, of course, very crude, as many uncontrolled variables, such as respiration rate, proportion of respirable dust, and times of exposure and of urine collection, change the relationship between the metal concentrations in the air and urine. What is evident is that the absorption and transport of chromium (III) to urine from its complex with lignosulfonate is relatively rapid. The half-time of chromium in the urine was also short, 4-10 h; a corresponding figure of 15 to $41 \mathrm{~h}$ was obtained for chromium (VI) from welding fumes (13).

The photoelectron spectrum of chromium lignosulfonate indicates that the chromium is in the trivalent oxidation state. A shoulder was noted in the peaks of the chromium (III) standard and in those of chromium lignosulfonate; however this finding does not indicate the presence of chromium (VI) in the samples concerned but is probably due to shake-up satellites or multiplet splitting (8). The phenomenon was more pronounced with the high-purity chromium (III) oxide standard than with chromium lignosulfonate. The diphenylcarbazide reaction confirmed the valence state of chromium in an aqueous solution. It is concluded that chromium in lignosulfonate occurs exclusively in the trivalent oxidation state. This circumstance is to be expected since chromium (III) is the most stable of the oxidation states of chromium and in acid solutions chromium (VI) is generally very effectively reduced, especially in the presence of organic matter $(5,7,10)$.

\section{Acknowledgments}

Thanks are due to $\mathrm{Mr} \mathrm{P}$ Mäkelä for his skillful technical assistance in collecting and analyzing the industrial hygiene samples and to Ms A Grundström, Ms M Partanen, and Ms S Vento for analyzing the biological samples. The X-ray photoelectron spectroscopy was performed by E Minni, PhL, University of Turku, Finland. The study was made possible by the very positive attitude of the directors of the company concerned and by the smooth cooperation of the participating employ- 
ees. Thanks are also due to Ms E Heseltine for editing the text.

\section{References}

1. Axelson G, Rylander R. Environmental chromium dust and lung cancer mortality. Environ res 23 (1980) 469-476.

2. Axelson G, Rylander R, Schmidt A. Mortality and tumor incidence among ferrochromium workers. $\mathrm{Br} \mathrm{j}$ ind med 37 (1980) 121-127.

3. de Flora S. Study of 106 organic and inorganic compounds in the Salomonella/microsome test. Carcinogenesis 2 (1981) 283298.

4. Gylseth B, Gundersen N, Langard S. Evaluation of chromium exposure based on a simplified method for urinary chromium determination. Scand j work environ health 3 (1977) 28-31.

5. International Agency for Research on Cancer. Chromium and chromium compounds. In: International Agency for Research on Cancer. Some metals and metallic compounds. Lyon 1980, pp 205323. (IARC monographs on the evaluation of the carcinogenic risk of chemicals to humans, volume 23).

6. Korallus U, Ehrlicher H, Wustefeld E. Dreiwertige Chromverbindungen: Ergebnisse einer arbeitsmedizinischen Undersuchung. Arbeitsmed Sozialmed Praventivmed 11 (1974) 248-252.
7. Langard S, Norseth T. Chromium. In: Friberg L, Nordberg GF, Vouk VB, ed. Handbook on the toxicology of metals. Elsevier, Amsterdam 1979, pp 383-397.

8. Lautner GM, Carver JC, Konzen RB. Measurement of chromium VI and chromium III in stainless steel welding fumes with electron spectroscopy for chemical analysis and neuron activation analysis. Am ind hyg assoc j 39 (1978) 651-660.

9. Mutti A, Cavatorta A, Pedroni C, Borghi A, Giaroli C, Franchini I. The role of chromium accumulation in the relationship between airborne and urinary chromium in welders. Int arch occup environ health 43 (1979) $123-133$.

10. National Academy of Sciences. Chromium. Washington, DC 1974.

11. National Institute of Occupational Health and Safety. Criteria for a recommended standard: Occupational exposure to chromium (VI). US Government Printing Office, Washington, DC 1975.

12. Tola S, Kilpio J, Virtamo M, Haapa K. Urinary chromium as an indicator of the exposure of welders to chromium. Scand $\mathrm{j}$ work environ health 3 (1977) 192-202.

13. Tossavainen A, Nurminen $P$, Mutanen $P$, Tola S. Application of mathematical modelling for assessing the biological half-times of chromium and nickel in field studies. $\mathrm{Br}$ $\mathrm{j}$ ind med 37 (1980) 285-291.

Received for publication: 11 November 1981 